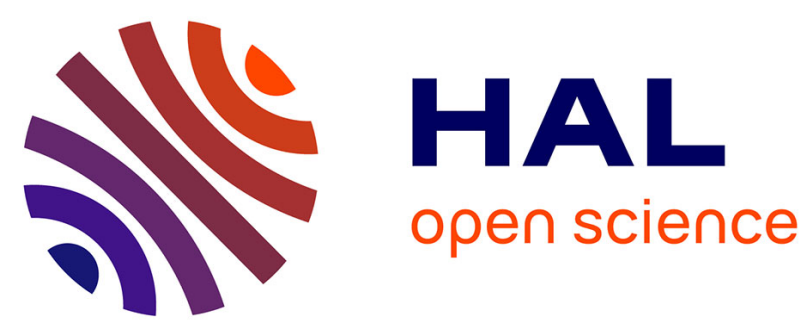

\title{
Simulation of Evaporation and Transpiration of Eggplant Under Mulch Drip Irrigation in Greenhouse
}

Zhiwei Zheng, Liuyan Yu, Xiushui Liu

\section{To cite this version:}

Zhiwei Zheng, Liuyan Yu, Xiushui Liu. Simulation of Evaporation and Transpiration of Eggplant Under Mulch Drip Irrigation in Greenhouse. 10th International Conference on Computer and Computing Technologies in Agriculture (CCTA), Oct 2016, Dongying, China. pp.152-159, 10.1007/978-3030-06155-5_15. hal-02179985

\section{HAL Id: hal-02179985 \\ https://hal.inria.fr/hal-02179985}

Submitted on 12 Jul 2019

HAL is a multi-disciplinary open access archive for the deposit and dissemination of scientific research documents, whether they are published or not. The documents may come from teaching and research institutions in France or abroad, or from public or private research centers.
L'archive ouverte pluridisciplinaire HAL, est destinée au dépôt et à la diffusion de documents scientifiques de niveau recherche, publiés ou non, émanant des établissements d'enseignement et de recherche français ou étrangers, des laboratoires publics ou privés. 


\title{
Simulation of Evaporation and Transpiration of Eggplant under Mulch Drip Irrigation in Greenhouse
}

\author{
Zhiwei Zheng ${ }^{1(\bowtie)}$, Liuyan $\mathrm{Yu}^{2}$, Xiushui Liu ${ }^{2}$ \\ ${ }^{1}$ Department of Hydraulic Engineering, Tianjin Agricultural University, Tianjin 300384, China \\ a zhiwei35883@163.com \\ ${ }^{2}$ Hebei Research Institute of Investigation Design of Water Conservancy Hydropower, Tianjin \\ 300250, China \\ ${ }^{\mathrm{b}}\{$ Yuliuyan, Liuxiushui\}@126.com
}

\begin{abstract}
Based on the principle of soil water balance, the change of soil water content during the whole growth period of eggplant with the variety "Angela" as the material is simulated through the test of greenhouse environmental factors. The crop coefficient is determined by the optimization method. The evapotranspiration of eggplant is simulated under the condition of drip irrigation under mulch film. The results showed that the simulated values of soil water content in the growth period of eggplant are in good agreement with the measured values, and the relative error is less than $10 \%$. The variation rule of the crop coefficient and eggplant leaf area index are consistent. The crop coefficient in the early increases gradually, in the vigorous growth period of crop coefficient reaches the maximum value of 0.518 , then began to decreases from 0.518 reduced to 0.505 and then increased gradually. The fluctuation is mainly affected by pruning management. The change of water requirement of eggplant in greenhouse is smaller in the early stage of growth between 0.2 $2.4 \mathrm{~mm} / \mathrm{d}$. And the change in the late of the growth period is larger between 0.1 $\sim 3.1 \mathrm{~mm} / \mathrm{d}$. The accumulated value of evaporation and transpiration increases gradually, and the highest value is $290 \mathrm{~mm} / \mathrm{d}$.
\end{abstract}

Keywords: drip irrigation under mulch film, eggplant, evaporation and transpiration, simulation

\section{Introduction}

The soil water content of root layer has great influence on the growth, yield and quality of eggplant. To explore the eggplant growth period of water requirement rules and the optimum irrigation scheme which determine the scientific and quantitative irrigation index and guide the agricultural production, alleviate the water shortage in agriculture, reduce waste of water in agriculture, improve agricultural water use efficiency etc. problem has important significance[1-4]. Evaporation and transpiration in vegetable research is generally under traditional irrigation condition, and mainly aims at different types of vegetables water requirement characteristic and different growth stages water requirement characteristic and different natural conditions of vegetables water requirement rules to conduct qualitative analysis. However, due to 
the different irrigation drainage and field management measures, the micro climate environment of crop growth has also changed a lot. The research results obtained under the traditional production conditions are obviously not suitable for the crop water requirement under the condition of drip irrigation in greenhouse. Calculation model for the domestic fruit and vegetable crops evapotranspiration is mainly to establish water requirement regression empirical model using meteorological factors and yield. The empirical model can be used for the calculation of crop water requirement in a certain period of time, but for different regions, it is necessary to accurately estimate crop water requirement in combination with local climatic conditions, and to correct the parameters of the formula [5-9].

\section{Experiments and Methods}

\subsection{Experimental Samples}

The experiment is carried out at the experimental base of the West Campus of Tianjin Agricultural University. The soil of the experimental area is loam, and the basic properties of the soil are shown in table 1. During the experiment, the planting of Eggplant in the greenhouse is Angela, and the planting date is September 13, 2014. We have planted 55 ridge crops in the greenhouse, 1100 strains. Irrigation mode is the drip irrigation under mulch film. Emitter flow rate is $2.0 \mathrm{~L} / \mathrm{h}$. The length of one time irrigation was $280 \mathrm{~min}$.

Table 1. Soil basic feature

\begin{tabular}{cccccc}
\hline $\begin{array}{c}\text { Depth of soil } \\
/ \mathrm{cm}\end{array}$ & $\mathrm{pH}$ & $\begin{array}{c}\text { Salt content } \\
/ \mathrm{g} / \mathrm{kg}\end{array}$ & $\begin{array}{c}\text { Organic matter } \\
\text { content } / \%\end{array}$ & $\begin{array}{c}\text { Available } \\
\text { phosphorus } \\
/ \mathrm{mg} / \mathrm{Kg}\end{array}$ & $\begin{array}{c}\text { alkaline } \\
\text { nitrogen } / \mathrm{mg} / \mathrm{Kg}\end{array}$ \\
\hline 20 & 7.22 & 2.43 & 2.01 & 121.9 & 103.1 \\
40 & 7.34 & 1.98 & 1.35 & 93.7 & 79.4 \\
60 & 7.57 & 1.45 & 1.65 & 57.4 & 41.5 \\
80 & 7.21 & 1.32 & 1.32 & 43.2 & 31.4 \\
100 & 7.76 & 1.21 & 1.08 & 40.6 & 30.7 \\
\hline
\end{tabular}

\subsection{Experimental Methods}

Using the Internet of things system tests the soil moisture content which aims at the characteristics change. The Internet of things system terminal set up in the middle of the greenhouse, from the ground $2 \mathrm{~m}$. The video capture terminal is erected at the top of the greenhouse to ensure that the whole greenhouse can be monitored. In the data acquisition terminal system, air temperature and humidity sensors, solar radiation sensor are integrated in the Internet of things system terminal. Soil temperature and soil moisture sensors are embedded in the layered soil $(20 \mathrm{~cm}$ under the ground). In order to ensure that the internet of things system can achieve the desired goal and reliable operation, the first $\log$ terminal and data acquisition module respectively corresponding debugging, to ensure that each part can be normal and reliable 
operation. Only in ensuring the reliability of each part of the system under the premise of the system continues to carry out the relevant testing of the entire system until the desired target. Rectangle of blade can be seen as a rule, every time we measure crop longitudinal maximum length of the blade as the blade length calculation, horizontal maximum length as the blade width calculation, so the calculated area is equal to the length of blade, multiply, wide's production. The actual size of leaf samples gather from small to large series, and then back to the laboratory with laser scanning leaf area meter blade to abstain the actual area, finally find out the actual area and calculation area of the relationship. The corresponding calculation formula: $\mathrm{y}=0.6449 \mathrm{x}+9.2414$. The square of correlation coefficient is 0.8721 . $\mathrm{y}$ is the eggplant leaf measured area, $\mathrm{cm}^{2}$; $\mathrm{x}$ is eggplant leaf area calculation, $\mathrm{cm}^{2}$.

\subsection{Simulation Calculation of Evaporation and Transpiration}

We use the soil water correction coefficient to analyze the effect of insufficient water supply on crop water requirement. The calculation formula is as follows:

$$
E T=K_{s} K_{c} E T_{0}
$$

In the formula ( 1), ET represents fact crop water requirement, $\mathrm{mm} / \mathrm{d} . K_{s}$ represents correction coefficient which effects soil water deficiency in root zone on crop water requirement. $K_{c}$ represents crop coefficient, which is related to the crop species, growth period and population leaf area index, and is a reflection of the biological characteristics of crops. $E T_{0}$ represents reference crop evapotranspiration, $\mathrm{mm} / \mathrm{d}$.

\subsubsection{Calculation of Crop Coefficient}

Many literatures show that the leaf area index of crop population and the crop coefficient are linear in a certain period of time:

$$
K_{c}=a L A I+b
$$

In the formula (2), $K_{C}$ represents crop coefficient of eggplant. LAI represents the leaf area index. $a$ and $b$ represent coefficient of demand.

By using the least squares method to simulate and calculation of soil moisture content and the actual test of soil moisture minimum squared error objective function, we use the optimization inversion method to determine the value of $a$ and $b$. The objective function is as follows:

$$
S S=\min \sum_{j=1}^{N}\left(\theta_{j}-\hat{\theta}_{j}\right)^{2}
$$

In the formula (3), SS represents the objective function. $\theta_{j}$ and $\hat{\theta}_{j}$ represent measured and simulated values of soil water content. $N$ is Test quantity.

In this experiment, the water content of soil $\hat{\theta}_{j}$ is simulated by using $0-100 \mathrm{~cm}$ soil water balance equation. 
The results of each parameter in the iterative calculation are shown in Table 2.

Table 2 Validation and calibration of eggplant crop coefficient parameters

\begin{tabular}{ccc}
\hline Parameter & Initial value & Optimal value \\
\hline a & 0.2 & 0.100 \\
b & 0.3 & 0.717 \\
SS & 107.46 & 16.31 \\
Sample quantity & & 20 \\
Standard deviation & & 0.96 \\
\hline
\end{tabular}

\subsubsection{Calculation of soil water correction coefficnient}

The Jansen calculation model is as follows:

$$
\begin{gathered}
K_{s}=\left\{\begin{array}{cc}
1 & \theta \geq \theta_{j} \\
\frac{\ln (A W+1)}{\ln (101)} & \theta_{j}>\theta \geq \theta_{w p} \\
0 & \theta<\theta_{w p}
\end{array}\right. \\
A W=\frac{\theta-\theta_{w p}}{\theta_{c r}-\theta_{w p}}
\end{gathered}
$$

In the formula, Ks represents soil water correction coefficient. AW represents real effective soil moisture percentage. $\theta$ is the moisture content of soil root layer. $\theta_{c r}$ is the moisture content of soil is affected by the water deficit. Reference to the existing research literature, $\theta_{c r}=0.90 \theta_{c} . \theta_{c}$ represents field water holding capacity. $\theta_{w p}$ represents crop wilting water content, by experiment $\theta_{w p}=0.2 \theta_{c}, \theta_{c}=0.28$ $\mathrm{cm}^{3} / \mathrm{cm}^{3}$.

\section{Results Analysis}

\subsection{Changes of Leaf Area Index of Eggplant with Time}

The variation of leaf area index with time is drawn by using the conversion coefficient and the test results. Eggplant leaf area index from 0.63 initial increases gradually, after reaching the peak value appeared in the first increase and then decrease, and then increase the volatility process, the main reason is the eggplant pruning management measures. We get the maximum value of the leaf area index of eggplant in the whole growth period is 1.07 , and the minimum is 0.53 . 


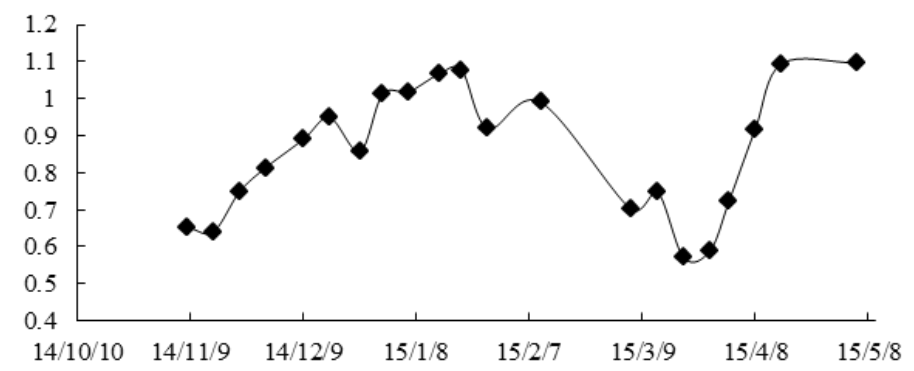

Fig.1 Dynamic curve of eggplant leaf area index

\subsection{Irrigation Amount of Eggplant}

The irrigation time and irrigation amount of eggplant were given in Fig 2. The irrigation quota is changed from 32 to $50 \mathrm{~mm}$. The number of irrigation times is 12 times. The irrigation quota is $510 \mathrm{~mm}$.

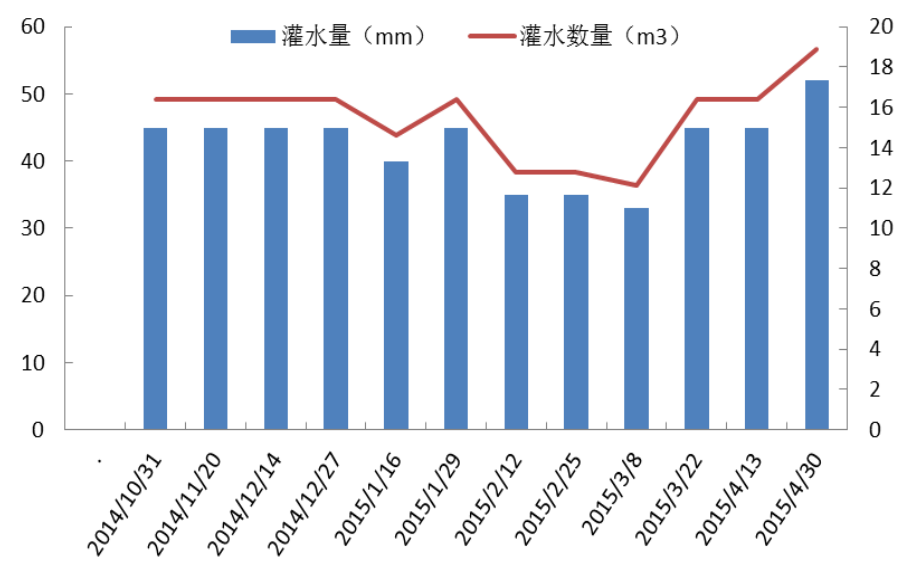

Fig.2 Corresponding Irrigation Amount

\subsection{Comparison between Simulated and Measured values}

From figure 3, we can see that the simulated values of soil moisture content in eggplant growing season coincide with the measured values, and the relative error between them is relatively small. 


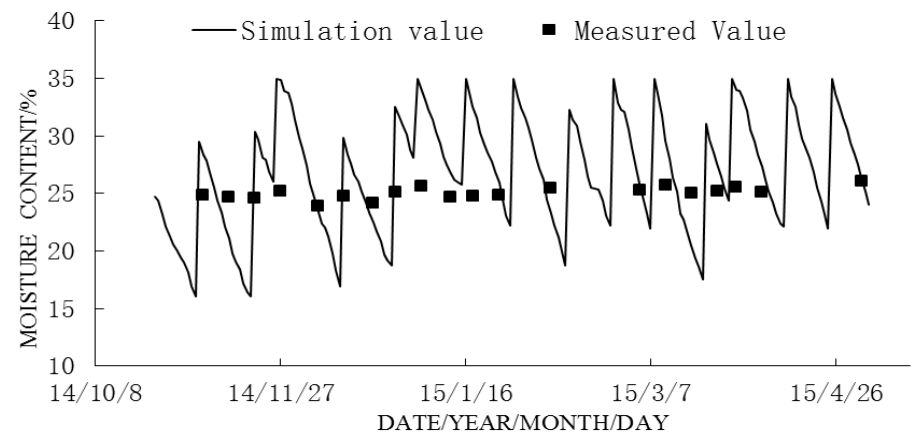

Fig.3 Simulation and Measured Values of Soil Moisture Content of Eggplant

\subsection{Variation Law of Crop Coefficient}

The variation rule of the crop coefficient and eggplant leaf area index are consistent. The crop coefficient in the early increases gradually, in the vigorous growth period of crop coefficient reaches the maximum value of 0.518 , then began to decreases from 0.518 reduced to 0.505 and then increased gradually. The fluctuation is mainly affected by pruning management.

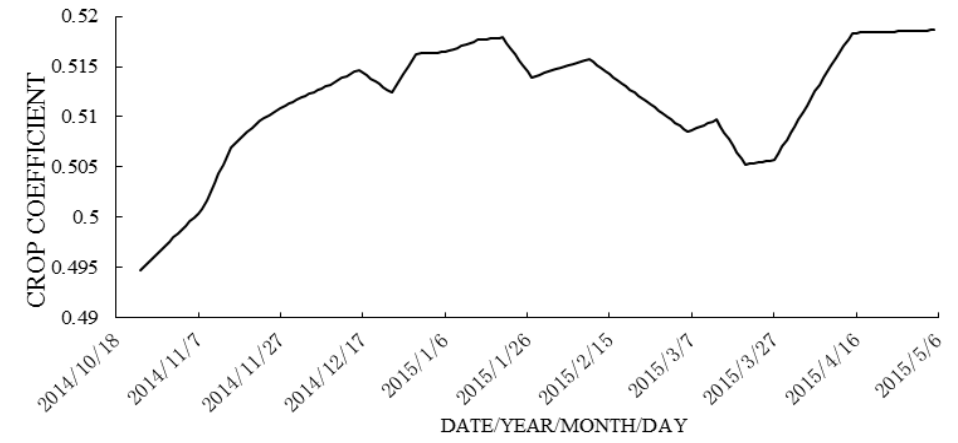

Fig.4 The Variation of Eggplant Crop Coefficient with Time

\subsection{Changes of Evapotranspiration}

From Figure 5, we can see that the change of water requirement of eggplant in greenhouse is smaller in the early stage of growth between $0.2 \sim 2.4 \mathrm{~mm} / \mathrm{d}$. And the change in the late of the growth period is larger between $0.1 \sim 3.1 \mathrm{~mm} / \mathrm{d}$. The accumulated value of evaporation and transpiration increases gradually, and the highest value is $290 \mathrm{~mm} / \mathrm{d}$. 


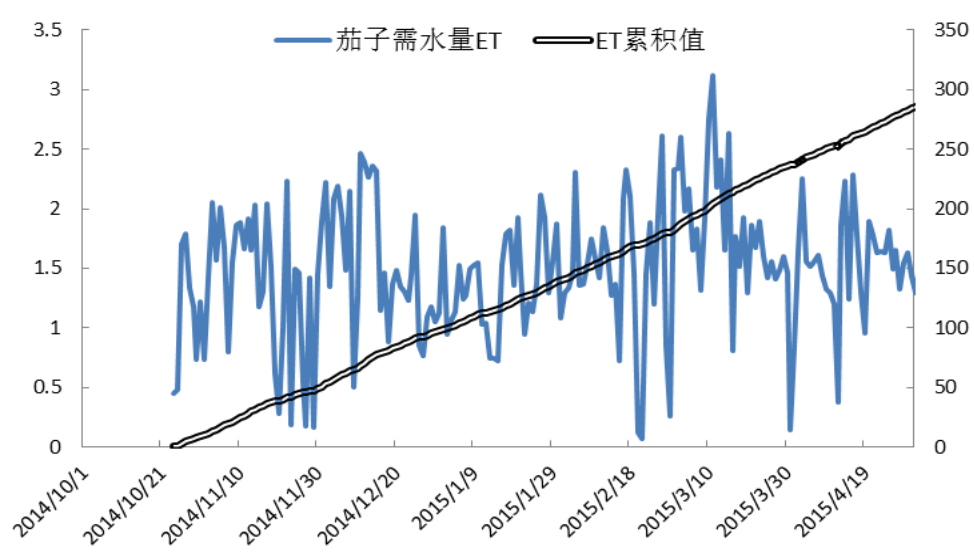

Fig.5 The Variation of Eggplant Crop Coefficient

\section{Conclusions}

According to the method of parameter inversion, the variation law of the variation law of the crop leaf area index is consistent with the suitable crop coefficient which is determined by the local climate and crop conditions. The crop coefficient affected by pruning management, performance is first increased and then decreased trend to increased volatility.

The variation of evapotranspiration of Eggplant is that the evapotranspiration is smaller in the prophase of growth between $0.2 \sim 2.4 \mathrm{~mm} / \mathrm{d}$. And the change in late of the growth period is larger between $0.1 \sim 3.1 \mathrm{~mm} / \mathrm{d}$.

Crop evapotranspiration calculation model is the main content. And the calculation of crop evapotranspiration is mainly depended on reference crop evapotranspiration and crop coefficient. The soil moisture correction coefficient is introduced, and the most reliable way to obtain the crop evapotranspiration is obtained by the measured method.

\section{Acknowledgment}

Funds for this research was provided by Tianjin Science and Technology Support Key Project (18YFZCSF00650), Tianjin Science and Technology Project (17PTSYJC00110), Tianjin Wuqing Science and Technology Development Project (WQKJ201804), Tianjin University Students' Innovation and Entrepreneurship Training Project (201710061028). 


\section{References}

1. Dong W, Zhang L, Duan Y, et al. Ridge and furrow systems with film cover increase maize yields and mitigate climate risks of cold and drought stress in continental climates[J]. Field Crops Research, 2017, 207:71-78.

2. Travella, S. and Keller, B. (2009) Down-regulation of gene expression by RNA-induced gene silencing. In Transgenic Wheat, Barley and Oats, Volume 478 (Jones, H.D. and Shewry, P.R. eds.). Methods in Molecular Biology, Humana Press, Springer, New York, pp. $185-199$.

3. Ogle K, et al. Differential daytime and night-time stomatal behavior in plants from North American deserts. New Phytol, 2012,194(2):464-476.

4. Schoppach R, Claverie E, Sadok W. Genotype-dependent influence of night-time vapour pressure deficit on night-time transpiration and daytime gas exchange in wheat. Funct Plant Biol, 2014, 41(9):963-971.

5. Aude Coupel-Ledru, Eric Lebon, Angélique Christophe, et al. Reduced nighttime transpiration is a relevant breeding target for high water-use efficiency in grapevine[J]. National Academy of Sciences, 2016, 113 (32) 8963-8968.

6. Senthil-Kumar Muthappa, Udayakumar Makarla, Mysore Kirankumar S. Functional characterization of water-deficit stress responsive genes using RNAi [J]. Methods in Molecular Biology, 2010, 639:193-206.

7. Chen Xinming, CaiHuanjie, Li Hongxing et al. Calculation of crop evapotranspiration in greenhouse [J].Chinese Journal of Applied Ecology, 2007,18(2):317-321.

8. Wang Shu, Li Guangyong, Meng Guoxia et al. Effects of dripper discharge and spacing on growth of cucumber in Chinese solar greenhouse under drip irrigation [J].Transactions of the CSAE, 2005,21(10):167-170.

9. Kang $\mathrm{S} \mathrm{Z}, \mathrm{Gu} \mathrm{B} \mathrm{J}, \mathrm{Du} \mathrm{T} \mathrm{S}$ et al. Crop coefficient and ratio of transpiration to evapotranspiration of winter wheat and maize in a semi-humid region [J].Agricultural Water Management,2003,59(3):239-254.

10. Peng Zhigong, Duan Aiwang, Liu Zugui et al. Research on plant transpiration in eggplant in solar-heated greenhouse [J]. Irrigation and Drainage, 2002,21(2):47-50.

11. Liu Yanwei, Zhu Zhongyuan, Wu Yun et al. Comparison of evapotranspiration of the natural vegetation in the otindag sandy area using two calculation methods[J].Transactions of the Chinese Society for Agricultural Machinery,2010,41(11):84-88.

12. Zhang Zhenhua, CaiHuanjie, Yang Runya et al. Water requirements and crop coefficients of drip-irrigated crop under mulch in Minqin County Oasis[J].Transactions of the CSAE, 2004,20(5):97-100.

13. Allen R G, Pereira L S, Raes D, Smith M, 1998. Crop Evapotranspiration: Guidelines for Computing Crop Water Requirement. FAO Irrigation and Drainage Paper No 56,FAO,Rome.

14. Zhao Weixia, Li Jiusheng, Wang Zhen. Estimation of water consumption as affected by measurement locations of soil water content in drip irrigated tomato in solar greenhouses [J]. Chinese Journal of Eco-Agriculture, 2014, 22(1):37-43.

15. Xiao Juan, Lei Tingwu, Li Guangyong et al. Crop coefficients and water use of watermelons and honeydew melons in saline water drop irrigation [J]. Journal of Hydraulic Engineering, 2004(6):119-123.

16. Hossein T. Evaluation of reference crop evapotranspiration equations in various climates [J]. Water Resources Management, 2010, 24(10):2311-2337. 